\title{
PEMODELAN NUMERIK KEKUATAN PINTU AIR BAJA
}

\section{THE NUMERICAL MODEL OF THE STEEL FLOOD GATE STRENGTH}

\author{
Fitriansyah $^{* 1}$, Miftahul Iman ${ }^{2}$, Aminullah $^{3}$ \\ ${ }^{1}$ Dosen, Teknik Sipil, Fakultas Teknik, Universitas Achmad Yani Banjarmasin \\ ${ }^{2}$ Dosen, Teknik Sipil, Fakultas Teknik, Universitas Borneo Tarakan \\ ${ }^{3}$ Dosen, Teknik Sipil, Fakultas Teknik, Universitas Nahdlatul Ulama Kalimantan Selatan \\ Korespondensi: fitriansyah@uay.ac.id
}

\begin{abstract}
ABSTRAK
Bangunan intake untuk Embung Sei Bubu telah dirancang untuk menjadi saluran terbuka dengan gerbang banjir. Gerbang banjir telah dirancang dari baja dengan lebar bersih 1,35 $\mathrm{m}$ dan ketinggian bukaan pintu 0,0076 m. Korosi merupakan salah satu ancaman berbahaya bagi kekuatan dan daya tahan gerbang banjir. Penelitian ini secara numerik memodelkan gerbang banjir yang diserang oleh korosi lubang. Korosi lubang telah dimodelkan dalam beberapa lubang kecil secara acak didistribusikan di permukaan pintu banjir. Efek dari level air telah dimasukkan. Pemodelan numerik telah dilakukan dalam metode elemen hingga memanfaatkan program komputer seperti Abaqus. Hasil penelitian menunjukkan ada penurunan kapasitas gerbang banjir baja karena lubang meningkat. Penurunan kapasitas tegangan telah ditunjukkan oleh tegangan yang terjadi di sekitar korosi lubang. Penurunan tegangan terjadi dengan perubahan persentase area distribusi korosi pitting sebesar 85,47\% (70,62 MPa), 91,95\% (127,42 MPa) dan 82\% (57,04 MPa) untuk 2/3H. Perpindahan maksimum terjadi di IFM, sub model 2 dalam $16,39 \mathrm{~mm}$.
\end{abstract}

Kata Kunci: Baja, Korosi, Lubang, Pintu air, Tegangan

\begin{abstract}
The intake building for Embung Sei Bubu had been designed to be an open channel with the flood gate. The flood gate had been designed from steel with a net width of $1.35 \mathrm{~m}$ and the height of the door opening is $0.0076 \mathrm{~m}$. The corrosion is one of the hazardous threat to the strengthness and durability of the flood gate. This research numerically models flood gate that was attacked by pitting corrosion. The pitting corrosion had been modelled in several small holes randomly were distributed on the surface of the flood gate, precisely on the surface of the water. The numerical modeling had been performed in finite element method utilized computer programs such Abaqus. The results showed there was a reduction in the capacity of the steel flood gate due the hole increasing. The reduction in stress capacity had been indicated by the stress concentration that was occured around the pitting corrosion. The stress reduction occured with the change in the percentage of pitting corrosion distribution area of 10\% (225 MPa), 20\% (175 MPa) and 30\% (120 MPa).
\end{abstract}

Keywords: Corrosion, Flood gate. Hole, Steel, Stress 


\section{PENDAHULUAN}

Embung Sei Bubu telah dirancang untuk memenuhi kebutuhan air dasar untuk kebutuhan domestik, serta air irigasi untuk meningkatkan intensitas penanaman. Daerah irigasi yang potensial untuk dilayani adalah Daerah Irigasi Sei Bubu dengan total area pengembangan $200 \mathrm{Ha}$. Sei Bubu adalah salah satu sungai di Kabupaten Tanah Bumbu. Sungai ini membentang dari utara ke selatan dengan panjang hingga muara adalah $\pm 1,5$ $\mathrm{km}$. Bangunan intake untuk reservoir Sei Bubu telah dirancang di saluran terbuka dengan gerbang banjir.

\section{TINJAUAN PUSTAKA}

Dimensi gerbang banjir ditentukan berdasarkan ketinggian air di reservoir dan persyaratan maksimum untuk air irigasi dan air baku.

$$
A=\frac{Q}{C \cdot \sqrt{2 \cdot g \cdot H}}
$$

dengan:

$A:$ Luas pintu air

$Q:$ Debit

$C$ : Koefisien debit untuk saluran terbuka $(=0.60)$

$g$ : Percepatan gravitasi

$H$ : Tinggi kehilangan energy pintu air

Alex dkk. (2017) menyajikan pemanfaatan model numerik untuk menentukan gaya hidrodinamik yang bekerja pada pintu air gerobak datar, yang digunakan dalam karya pengalihan PLTA. Triatmodjo (1990) menjelaskan bahwa tekanan hidrostatik yang dilakukan pada penampang pintu air dapat dihitung dengan menggunakan Persamaan 2.

$$
P=\rho g h
$$

dengan $P$ adalah tekanan hidrostatik $\left(\mathrm{N} / \mathrm{m}^{2}\right)$, $\rho$ adalah massa jenis air $\left(\mathrm{kg} / \mathrm{m}^{3}\right), g$ adalah percepatan gravitasi $\left(\mathrm{m} / \mathrm{s}^{2}\right)$, dan $h$ adalah ketinggian air (m).

James (2015) Banjir yang terjadi di Jakarta sudah menjadi hal biasa bagi masyarakat yang tinggal di sana. Hampir setiap tahun banjir menggenangi jalan utama dan daerah perumahan.
Fenomena ini tentu menjadi perhatian banyak orang karena memengaruhi kehidupan ekonomi masyarakat sekitar. Salah satu penyebabnya adalah berkurangnya kapasitas saluran sungai Ciliwung.

Daniel (2010) Pemodelan pergerakan air banjir dapat dicapai dengan menggunakan banyak metode berbeda dengan berbagai tingkat detail fisik. Model numerik yang menggunakan metode perutean sederhana atau versi persamaan Navier-Stokes yang disederhanakan dapat digunakan untuk meningkatkan kesiapsiagaan banjir publik.

Miftahul dkk. (2018) Korosi pitting sering terdapat berupa lubang kecil pada baja tubular dari sebuah struktur platform ketika lapisan pelindung korosi (coating) telah rusak. Sebuah lubang tunggal pada elemen tekan yang langsing dapat menyebabkan pengurangan yang signifikan terhadap kapasitas tekuk batang. Penelitian ini dilakukan untuk mempelajari secara numerik pengaruh lubang bundar terhadap kapasitas tekuk baja tubular langsing.

\section{METODE}

Penelitian ini adalah studi numerik berdasarkan metode elemen hingga yang memodelkan saluran irigasi (Gambar.1). Model dalam penelitian ini terdiri dari dua model, model pintu air tanpa korosi lubang dan model pintu air dengan korosi lubang. Korosi pitting pada penelitian ini dimodelkan sebagai lubang-lubang kecil yang terdistribusi pada permukaan pelat baja gerbang banjir. Model pintu banjir dengan lubang telah dikelompokkan menjadi 3 sub model berturut-turut, yaitu: sub model 1, sub model 2, dan sub model 3. Distribusi korosi lubang di mana terletak di bagian atas, tepi dan tengah pelat. Jumlah lubang telah ditentukan sebanyak 5 buah per distribusi.

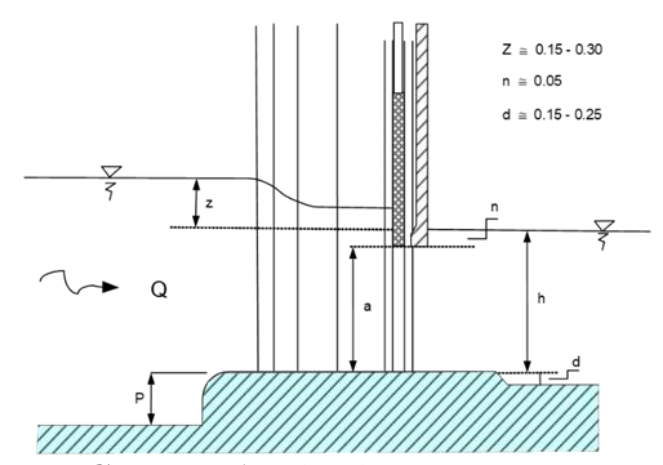

Gambar 1. Flood gate prototype 


\section{Perfect model (PFM)}

Pemodelan numerik pintu banjir (Gbr.2) menggunakan kombinasi elemen heksahedron padat dan tetrahedron yang tersedia di Abaqus. Model ini terdiri dari 3 bagian, yaitu profil UNP $120 \times 55$ x 3,8;

Profil L75 x 75 x 7 dan pelat tebal $10 \mathrm{~mm}$ terbuat dari baja. Tiga bagian dihubungkan oleh kendala dasi. Kondisi batas diidealkan dengan dukungan sederhana.

Beban pada model didefinisikan sebagai tindakan tekanan hidrostatik pada permukaan pelat baja gerbang banjir. Tekanan hidrostatik diperoleh dengan rumus hidrostatik (Persamaan 2) dimana dilakukan pada $0,50 \mathrm{H}$ dan $2 / 3 \mathrm{H}(\mathrm{H}=$ ketinggian pintu air) pada permukaan pelat baja model gerbang banjir.

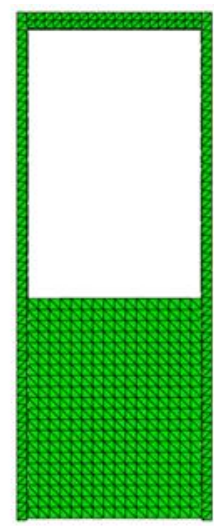

Gambar 2. Flood gate model

Gambar. 2 menunjukkan bahwa model pintu banjir dikonfigurasi dalam model padat. Model ini menggunakan elemen hexahedron dengan perkiraan ukuran global adalah 25 (Gbr. 3). Pelat baja diberi penyangga bersama dengan perpindahan arah vertikal (U3) tidak sama dengan nol. Ini dilakukan karena pelat baja dimungkinkan bergerak secara vertikal. Pelat baja ditempatkan pada balok beton berukuran $10 \mathrm{~cm}$ x $10 \mathrm{~cm}$ x 135 $\mathrm{cm}$ sebagai model pelat beton untuk dasar saluran. Kekuatan tekan beton ditentukan (f) $20 \mathrm{MPa}$ dan rasio Poisson (v) 0,2.

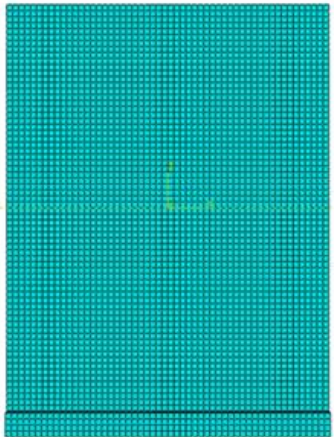

Gambar 3. Flood gate steel plate model

Balok beton telah dibatasi dengan pelat baja yang digunakan pembatas di Abaqus. Oleh karena itu pelat baja dan balok beton dapat merespons beban tekanan secara bersamaan. Permukaan air telah dievaluasi berdasarkan ketinggian pelat baja $(\mathrm{H}=1350 \mathrm{~mm})$. Ketinggian air telah ditentukan sebelumnya: 1 / 3H; 1 / 2H; 2 / 3H, di mana $\mathrm{H}$ adalah ketinggian pelat baja gerbang banjir.

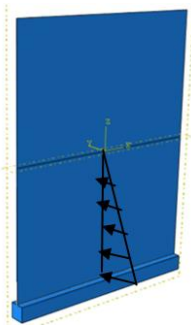

\section{Gambar 4. Hydrostatic pressure load}

Gambar. 4 menunjukkan bahwa beban bertindak sebagai beban tekanan hidrostatik. Tekanan hidrostatik telah tergantung pada ketinggian air. Dalam penelitian ini ketinggian air dikelompokkan menjadi 3 jenis. Ada $0,33 \mathrm{H}, 0,5 \mathrm{H}$, dan $0,67 \mathrm{H}$, di mana $\mathrm{H}$ adalah ketinggian pintu air.

\section{Imperfect Model}

Model tidak sempurna terdiri dari tiga sub model: sub model 1 , sub model 2 , dan sub model 3. Model-model tersebut telah dibedakan berdasarkan lokasi korosi pitting, mereka berada di kedua sisi pelat baja, di tengah-tengah pelat baja, dan di pelat baja atas selaras vertikal. Setiap model memiliki ketinggian air yang berbeda, $0,33 \mathrm{H}, 0,50$ $\mathrm{H}$, dan $0,67 \mathrm{H}$ di mana $\mathrm{H}$ adalah ketinggian air.

\section{Sub Model 1}

Sub model 1 memiliki korosi pitting di mana terletak di kedua sisi pelat baja (Gbr. 5). Model telah dibangun dalam tetrahedron dan elemen wedge dalam diskritisasi 25 elemen ukuran dalam idealisasi solid 3D. 


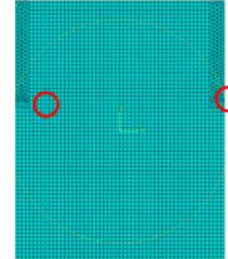

(a)

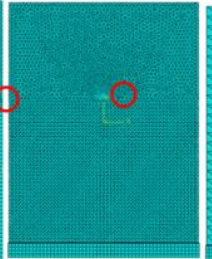

(b)

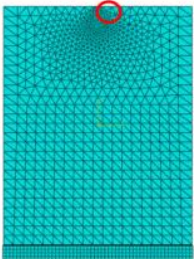

(c)
Gambar 5. The meshing of the sub model

Meshing di sekitar lubang ditentukan dalam elemen tetrahedron (Gambar 6). Lubang telah diidealkan oleh kecil (diameter $=5 \mathrm{~mm}$, dan kedalaman lubang 3,5 mm). Itu artinya lubang tidak bisa menembus pelat baja.

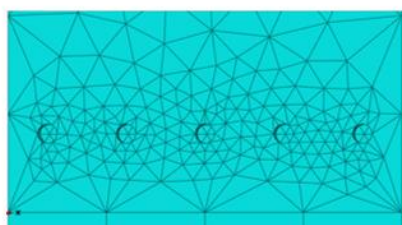

(a)

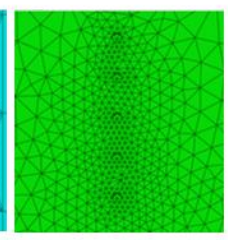

(b)
Gambar 6. Meshing around the hole

\section{HASIL DAN PEMBAHASAN}

Hasil penelitian telah dibagi menjadi dua model berturut-turut yaitu model pintu banjir tanpa efek korosi pitting (model pintu banjir sempurna, PFM) dan model pintu air dengan efek korosi lubang (model imperfect flood gate model, IFM). Model IFM terdiri dari tiga sub-model yang dibedakan oleh efek ketinggian airembahasan berisi tentang hasil penelitian yang telah dibandingkan dengan data-data yang diperoleh peneliti sebelumnya.

\section{Perfect Model (PFM)}

Output yang diperoleh dari PFM adalah stres dan perpindahan. Tegangan yang dievaluasi adalah kriteria stres maksimum (absolut) dan von mises. Evaluasi perpindahan telah difokuskan pada perpindahan tegak lurus (U2) dari pelat baja gerbang banjir.

Gambar. 7 menunjukkan kontur tegangan karena tekanan hidrostatik dilakukan pada permukaan pelat model gerbang banjir tanpa efek korosi pitting (PFM). Tegangan yang terjadi pada pelat berkisar antara 0,02-20,5 MPa dalam 2 / 3H, di mana $\mathrm{H}$ adalah kedalaman pelat baja gerbang banjir.
Tabel 1 menunjukkan bahwa tegangan rata-rata dan perpindahan terjadi dalam model gerbang banjir sempurna (tanpa penurunan kualitas). Tabel menunjukkan bahwa tegangan maksimum terjadi ketika level air dalam $1 / 2 \mathrm{H}$ dan 2/3H (10,67 MPa). Sebaliknya mereka memiliki perpindahan terendah dalam 2 arah $(0,41 \mathrm{~mm})$.

Table 1. Tegangan dan perpindahan (PFM)

\begin{tabular}{ccc}
\hline & $\begin{array}{c}\text { Tegangan rerata } \\
\text { von mises (MPa) }\end{array}$ & $\begin{array}{c}\text { Perpindahan } \\
(\mathrm{mm})\end{array}$ \\
\hline $0,33 \mathrm{H}$ & 4,25 & $-5,98$ \\
$0,50 \mathrm{H}$ & 10,27 & 0,41 \\
$0,67 \mathrm{H}$ & 10,27 & 0,41 \\
\hline
\end{tabular}

Tegangan terendah pada model sempurna (PFM) terjadi ketika permukaan air dalam 1 / 3H $(4,25 \mathrm{MPa})$, di mana $\mathrm{H}$ adalah ketinggian pelat baja. Perpindahan maksimum telah ditunjukkan pada Tabel 1 ketika permukaan air pada 1 / 3H $(-5,98)$. Perpindahan telah dipertimbangkan dalam 2 arah (U2).

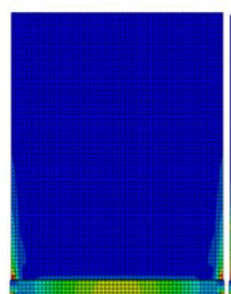

(a)

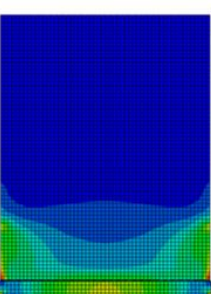

(b)

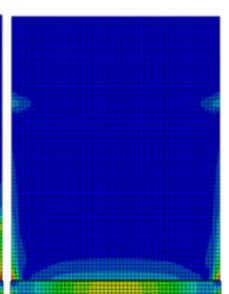

(c)
Gambar 7. Stress contour on PFM

Kontur tegangan (von mises) pada pelat baja telah dievaluasi ketika ketinggian air pada 0,3H adalah 4,22 MPa (Gambar. 7 (a)). Gambar. 7 (b) dan Gambar. 7 (c) menunjukkan bahwa pelat baja ketika tingkat air pada $0,5 \mathrm{H}$ dan $0,67 \mathrm{H}$ adalah 10,67 MPa.

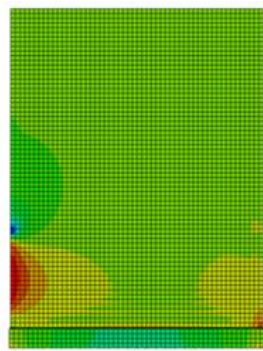

(a)

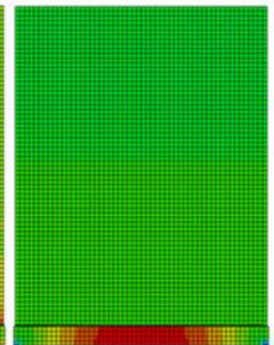

(b)

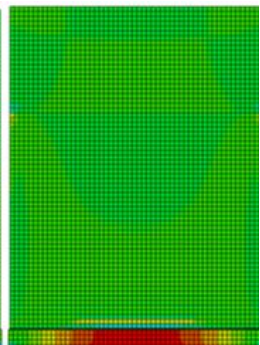

(c)
Gambar 8. Stress contour (PFM, pressure)

Kontur tegangan (tekanan) telah ditunjukkan pada Gambar. 8 dengan ketinggian air yang 
berbeda. Tegangan maksimum ditunjukkan pada $0,95 \mathrm{MPa}$ ketika level air dalam $1 / 3 \mathrm{H}$. Kontur pemindahan (U2) telah disajikan pada Gambar.9.

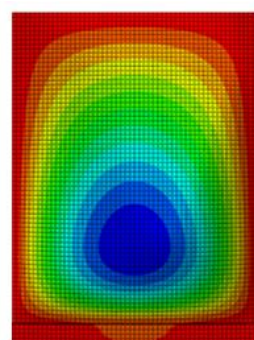

(a)

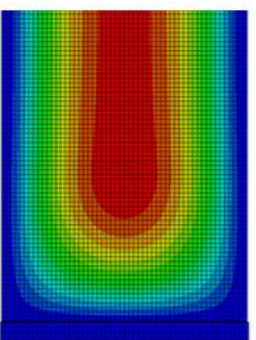

(b)

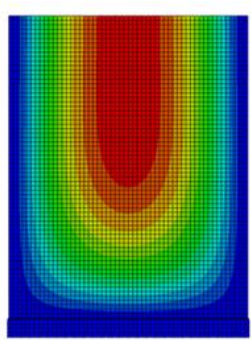

(c)
Gambar 9. Displacement contour $\left(\mathrm{U}_{2}, \mathrm{PFM}\right)$

\section{Imperfect Model (IFM)}

Model pintu banjir yang tidak sempurna terdiri dari tiga submodel yang dibedakan berdasarkan tingkat distribusi korosi lubang. Sub model pertama adalah pelat di mana distribusi korosi lubang ditemukan di kedua tepi pelat pintu banjir (Sub model 1). Sub model kedua adalah pelat yang memiliki distribusi korosi pitting di tengah pelat pintu banjir (Sub model 2). Sub model ketiga dari pelat yang memiliki distribusi korosi lubang di sisi atas pelat pintu banjir (Sub model 3).

\section{Sub model 1}

Sub model 1 memiliki tegangan luntur di sekitar lubang (von mises) mulai dari 4,22 $\mathrm{MPa}$ hingga 10,27 MPa (Gambar. 11).

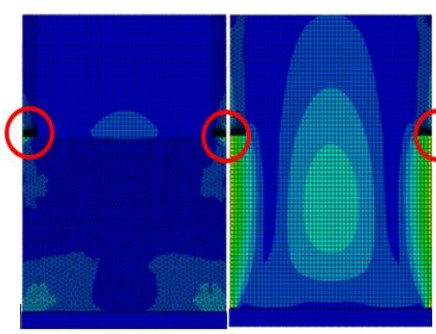

(a)

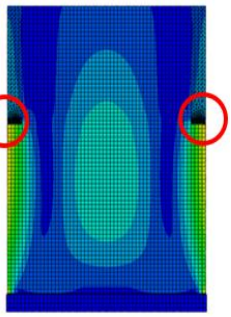

(c)
Gambar 10. Stress contour on IFM

Gambar 10 menunjukkan bahwa kontur tegangan (von mises) berbeda pada tiga kondisi keadaan permukaan air. Gambar. 10 (a) menunjukkan bahwa kontur tegangan terjadi ketika ketinggian air pada 0,3H. Gambar. 10 (b) dan Gambar. 10 (c) menunjukkan kontur tegangan dengan ketinggian air yang sesuai $0,5 \mathrm{H}$ dan $0,67 \mathrm{H}$.

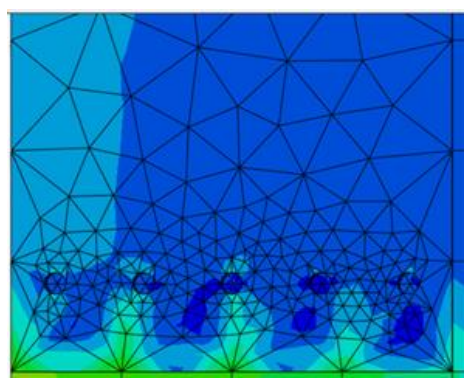

Gambar 11. Stress concentration at IFM 1

Gambar. 11 menunjukkan konsentrasi tegangan yang terjadi pada mengelilingi lubang di kedua sisi pelat baja model pintu banjir.

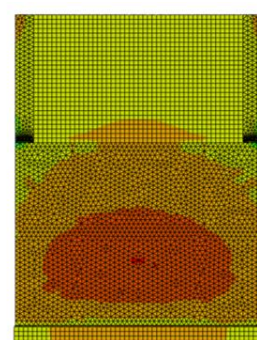

(a)

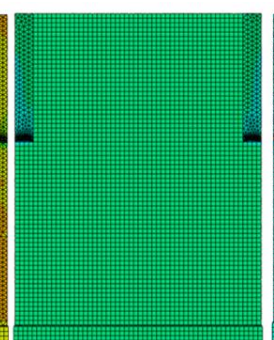

(b)

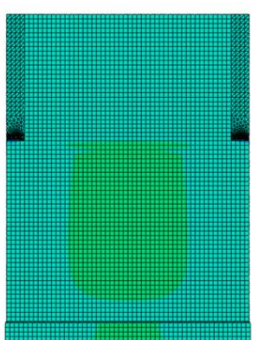

(c)
Gambar 12. IFM 1 stress (pressure)

Gambar 12 menunjukkan bahwa kontur tegangan (tekanan) berbeda tiga kondisi keadaan ketinggian air. Gambar. 12(a) menunjukkan bahwa kontur tegangan (tekanan) terjadi ketika ketinggian air pada 0,3H. Gambar. 12(b) dan Gambar. 12(c) menunjukkan kontur tegangan dengan ketinggian air yang sesuai $0,5 \mathrm{H}$ dan $0,67 \mathrm{H}$.

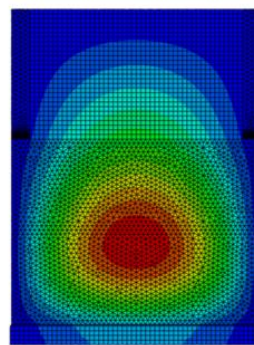

(a)

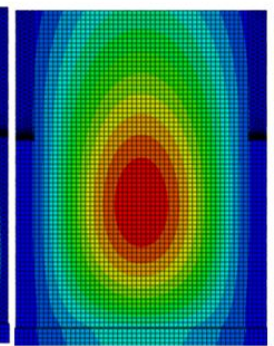

(b)

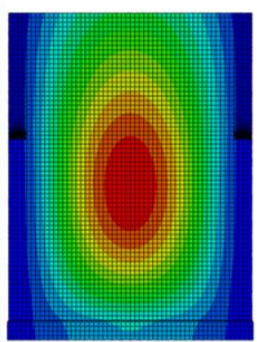

(c)
Gambar 13. IFM 1 stress (pressure)

Gambar 13 menunjukkan bahwa kontur perpindahan (von mises) berbeda tiga kondisi tingkat permukaan air. Gambar. 12 (a) menunjukkan bahwa kontur perpindahan (tekanan) terjadi ketika ketinggian air pada 0,3H. Gambar. 12 (b) dan Gambar. 12 (c) menunjukkan kontur perpindahan dengan ketinggian air yang sesuai $0,5 \mathrm{H}$ dan $0,67 \mathrm{H}$. 
Pemodelan Numerik Kekuatan...., Fitriansyah ${ }^{(1)}$, Miftahul Iman $^{(2)}$, Aminullah $^{(3)}$

Table 2. Tegangan dan perpindahan(IFM 1)

\begin{tabular}{|c|c|c|}
\hline & $\begin{array}{l}\text { Tegangan rerata } \\
\operatorname{vm}(\mathrm{MPa})\end{array}$ & Perpindahan (mm) \\
\hline $0,33 \mathrm{H}$ & 50,04 & 2,11 \\
\hline $0,50 \mathrm{H}$ & 40,41 & 1,40 \\
\hline $0,67 \mathrm{H}$ & 70,62 & 2,46 \\
\hline
\end{tabular}

\section{Sub model 2}

Sub model 2 memiliki tegangan di sekitar lubang mulai dari 145 hingga $175 \mathrm{MPa}$ (von mises). Konsentrasi tegangan yang mengelilingi lubang telah dievaluasi dalam $35 \mathrm{MPa}$ hingga $75 \mathrm{MPa}$.

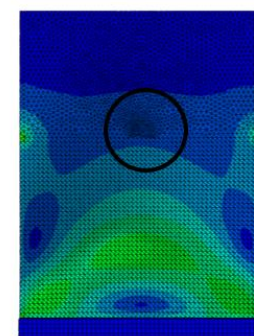

(a)

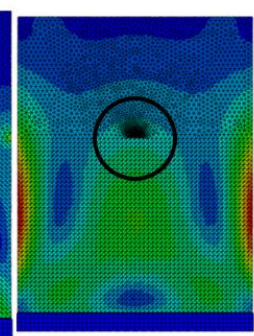

(b)

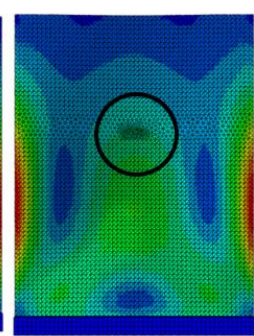

(c)
Gambar 14. Stress contour on IFM 2 Von Mises

Gambar. 14 menunjukkan bahwa kontur stres (von mises) berbeda tiga kondisi keadaan permukaan air. Gambar. 14 (a) menunjukkan bahwa kontur tegangan terjadi ketika ketinggian air pada $0,3 \mathrm{H}$. Gambar. 14 (b) dan Gambar 14 (c) menunjukkan kontur tegangan dengan ketinggian air yang sesuai $0,5 \mathrm{H}$ dan $0,67 \mathrm{H}$.

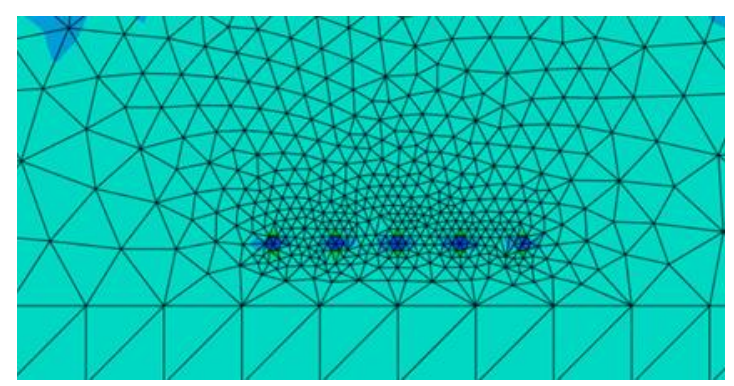

Gambar 15. Stress concentration at IFM 2

Gambar. 15 menunjukkan konsentrasi tegangan yang terjadi pada mengelilingi lubang di kedua sisi pelat baja model gerbang banjir.

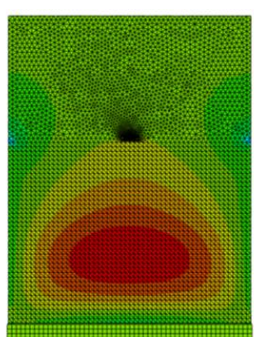

(a)

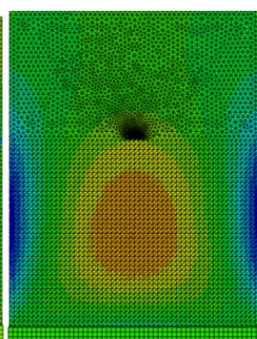

(b)

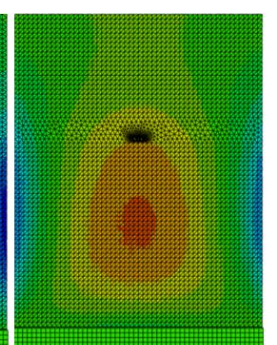

(c)
Gambar 16. Stress contour (pressure, submodel 2)

Gambar. 16 menunjukkan bahwa kontur tegangan (tekanan) berbeda tiga kondisi keadaan ketinggian air. Gambar. 16 (a) menunjukkan bahwa kontur tegangan (tekanan) terjadi ketika ketinggian air pada 0,3H. Gambar. 16 (b) dan Gambar. 16 (c) menunjukkan kontur tegangan dengan ketinggian air yang sesuai $0,5 \mathrm{H}$ dan $0,67 \mathrm{H}$.

Table 3 Stress and Displacement (IFM 2)

\begin{tabular}{ccc}
\hline & $\begin{array}{c}\text { Average stress } \\
\text { vm }(\mathrm{MPa})\end{array}$ & Displacement $(\mathrm{mm})$ \\
\cline { 2 - 3 } $0,33 \mathrm{H}$ & 46,85 & 5,50 \\
$0,50 \mathrm{H}$ & 97,57 & 11,99 \\
$0,67 \mathrm{H}$ & 127,42 & 16,39 \\
\hline
\end{tabular}

Tabel 3. menunjukkan bahwa tegangan maksimum dan perpindahan pada submodel 2 ketika ketinggian air pada $2 / 3 \mathrm{H}$. Tegangan minimum dan dispelement terjadi ketika level air pada $1 /$ $3 \mathrm{H}$.

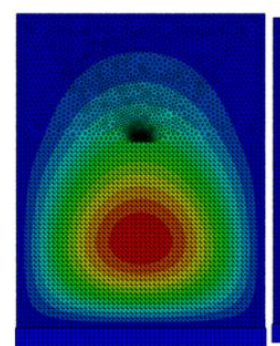

(a)

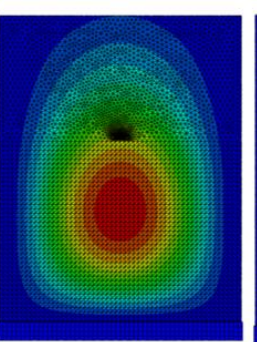

(b)

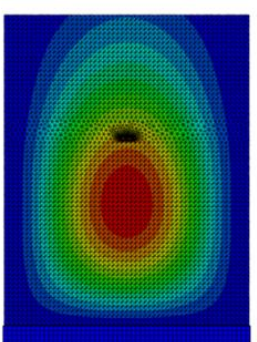

(c)
Gambar 17. Displacement contour (U2)

Gambar. 17 menunjukkan bahwa kontur perpindahan (von mises) berbeda tiga kondisi keadaan ketinggian air. Gambar 17 (a) menunjukkan bahwa kontur perpindahan (tekanan) terjadi ketika ketinggian air pada 0,3H. Gambar. 17 (b) dan Gambar. 17 (c) menunjukkan kontur perpindahan dengan ketinggian air yang sesuai $0,5 \mathrm{H}$ dan $0,67 \mathrm{H}$. 


\section{Sub model 3}

Sub model 3 memiliki tegangan di sekitar lubang mulai dari $75 \mathrm{MPa}$ hingga $125 \mathrm{MPa}$ (von mises, Gambar.8 (a)).

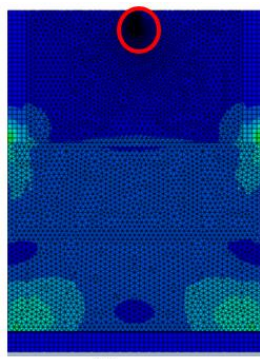

(a)

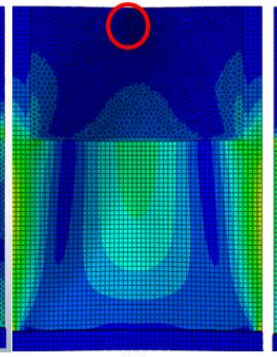

(b)

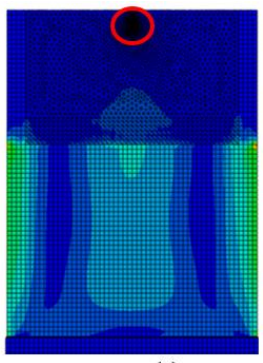

(c)
Gambar 18. Stress contour IFM Von Mises

Gambar. 18 menunjukkan bahwa kontur stres (von mises) berbeda tiga kondisi keadaan permukaan air. Gambar 18 (a) menunjukkan bahwa kontur tegangan terjadi ketika ketinggian air pada 0,3 jam. Gambar. 18 (b) dan Gambar. 18 (c) menunjukkan kontur tegangan dengan ketinggian air yang sesuai $0,5 \mathrm{H}$ dan $0,67 \mathrm{H}$.

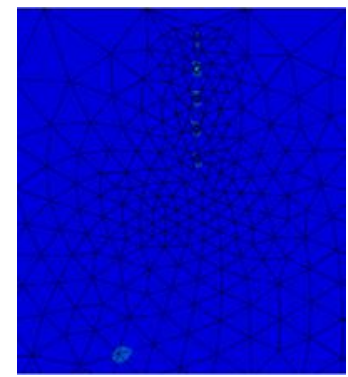

Gambar 19. Stress contour at IFM, submodel 3

Gambar. 19 menunjukkan konsentrasi tegangan yang terjadi pada mengelilingi lubang di kedua sisi pelat baja model pintu air.

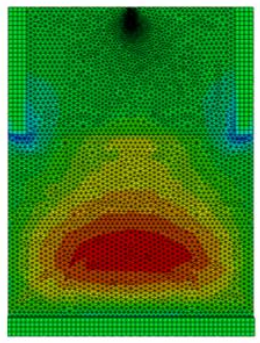

(a)

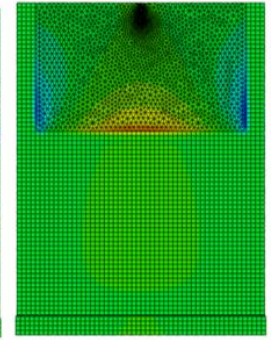

(b)

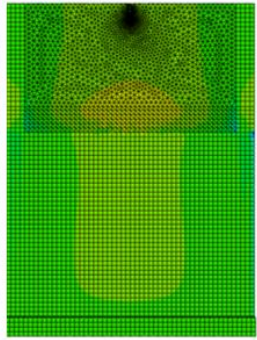

(c)
Gambar 20. Stress contour (pressure) sub model 3

Gambar 20 menunjukkan bahwa kontur tegangan (tekanan) berbeda pada tiga kondisi keadaan ketinggian air. Gambar 20 (a) menunjukkan bahwa kontur tegangan (tekanan) terjadi ketika ketinggian air pada 0,3H. Gambar 20 (b) dan Gambar. 20 (c) menunjukkan kontur tegangan dengan ketinggian air yang sesuai $0,5 \mathrm{H}$ dan $0,67 \mathrm{H}$.

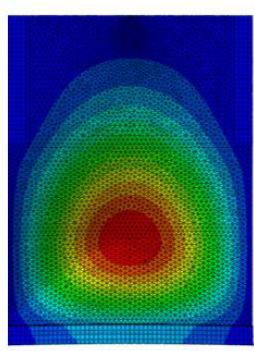

(a)

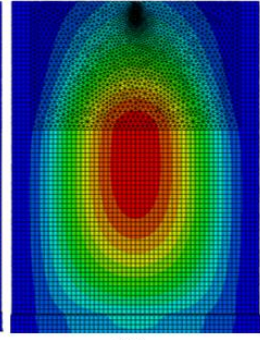

(b)

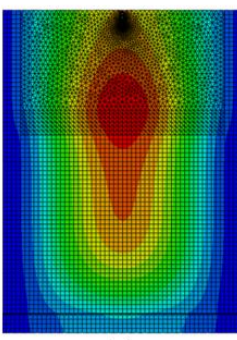

(c)
Gambar 21. Displacement contour $\left(U_{2}, I F M 3\right)$

Gambar. 21 menunjukkan bahwa kontur perpindahan (von mises) berbeda tiga kondisi keadaan ketinggian air. Gambar. 21 (a) menunjukkan bahwa kontur perpindahan (tekanan) terjadi ketika ketinggian air pada 0,3H. Gambar. 21 (b) dan Gambar. 21 (c) menunjukkan kontur perpindahan dengan ketinggian air yang sesuai $0,5 \mathrm{H}$ dan $0,67 \mathrm{H}$.

Table 3. Stress and Displacement (IFM 3)

\begin{tabular}{ccc}
\hline & $\begin{array}{c}\text { Average stress } \\
\text { vm }(\mathrm{MPa})\end{array}$ & Displacement $(\mathrm{mm})$ \\
\cline { 2 - 3 } $0,33 \mathrm{H}$ & 38,25 & 2,25 \\
$0,50 \mathrm{H}$ & 39,73 & 1,62 \\
$0,67 \mathrm{H}$ & 57,04 & 1,04 \\
\hline
\end{tabular}

Tabel 3 menunjukkan tegangan rata-rata (von mises) yang terjadi pada permukaan pelat dengan ketinggian air yang berbeda. Tabel menunjukkan bahwa sub model 3 dengan ketinggian air dalam 2 / $3 \mathrm{H}$ adalah tegangan maksimum $(57,04 \mathrm{MPa})$ tetapi memiliki perpindahan terendah $(1,04 \mathrm{~mm})$.

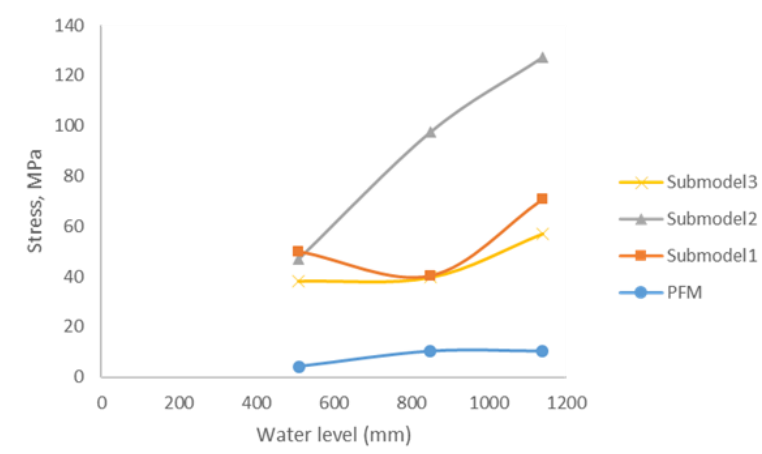

Gambar 22. Stress - water elevation curve

Gambar. 22 menunjukkan kurva elevasi air-stres dari model oleh efek elevasi air. 
Penurunan tegangan terjadi dengan perubahan persentase area distribusi korosi pitting sebesar $85,47 \%(70,62 \mathrm{MPa}), 91,95 \%$ (127,42 $\mathrm{MPa})$ dan $82 \%(57,04 \mathrm{MPa})$ dalam $2 / 3 \mathrm{H}$. Ini berarti keberadaan cacat pada permukaan pelat baja secara signifikan mempengaruhi kinerja dan daya tahan gerbang banjir.

\section{PENUTUP}

\section{Kesimpulan}

Hasil dari hasil ini telah disimpulkan sebagai berikut:

1. Hasil penelitian menunjukkan ada penurunan kapasitas pintu air baja karena lubang meningkat.

2. Penurunan kapasitas tegangan telah ditunjukkan oleh konsentrasi tegangan yang terjadi di sekitar lubang.

3. Penurunan tegangan terjadi dengan perubahan persentase area distribusi korosi pitting sebesar $85,47 \%$ (70,62 MPa), 91,95\% (127,42 MPa) dan $82 \%(57,04 \mathrm{MPa})$ dalam $2 / 3 \mathrm{H}$.

4. Perpindahan maksimum terjadi di IFM, sub model 2 dalam $16,39 \mathrm{~mm}$.

5. Lokasi korosi pengutipan di tengah pelat (IFM, sub model 2) lebih berbahaya daripada lokasi lain. kesimpulan dapat dibuat dalam bentuk paragraf atau dapat juga diuraikan per poin.

\section{DAFTAR PUSTAKA}

Alex, C. R, Luiz, F. M, Jairo, A. M, (2017), Numerical Simulation of Drainage in the Floodgate of a Diversion Tunnel of Hydroelectric Plants, Revista Espacios, Vol 38, Spanyol

Daniel, W. G, (2010), Application of Numerical Models for Improvement of Flood Preparedness, Nama Jurnal, Nomor terbit, Iowa

James, Z., (2015), Efektifitas Hidraulik Penambahan Pintu Air Melalui Uji Model Fisik 3D dan Model Numerik 1D (Studi Kasus: Pintu Air Manggarai), Jurnal Teknik Hidraulik, Vol 6 No. 01, Indonesia

Miftahul, I, Bambang, S, Hrc Priyosulistyo and Muslikh, (2018), Applied Mechanic and Materials, Trans Tech Publications, vol 881 UK

Triatmodjo, B, (1991), HIDRAULIKA 1, 1, Beta Offset Yogyakarta 